\title{
LETTER TO THE EDITOR Do we Need Functional Foods for the Treatment of Hypertension?
}

\author{
Evdoxia K. Mitsiou* \\ Department of Internal Medicine, Medical School, Aristotle University of Thessaloniki, Greece
}

Keywords: Arterial hypertension, non-pharmacological treatment, functional food, pomegranate juice.

\section{DEAR EDITOR}

I read with interest the Editorial by Dr. Tziomalos et al [1]. The use of "alternative" treatments or functional foods/beverages for the treatment of arterial hypertension is getting increasingly prevalent. The paper is in this direction, supporting this trend. However, there are some issues that might be related to the use of such treatment modalities.

First, is it possible that the use of pomegranate juice (PJ), a functional beverage, will reduce the adherence of hypertensive to the antihypertensive drug treatment that they might need for the effective control of their blood pressure? It has been shown that the use of functional foods or dietary supplements may offer opportunities to reduce health risk factors and risk of diseases, both as monotherapy and in combination with prescription drugs. Nevertheless, the potential caveats or false claims of these products should not be overlooked [2]. Should we jeopardize the necessary drug treatment for a functional food?

Second, authors mention that one of the mechanisms of action of PJ is angiotensin converting enzyme (ACE) inhibition. In a short term (4 weeks) study, results showed that PJ reduced blood pressure (BP), however the fall in BP was not paralleled by changes in concentration of serum ACE [3].

*Address correspondence to this author at the Department of Internal Medicine, Medical School, Aristotle University of Thessaloniki, Iraklias 11, Thessaloniki, 54 336, Greece; Tel: +30 2310 960855, Fax: +30 2310 835955; E-mail: mitsevi@gmail.com
Third, in the case that PJ indeed reduces ACE activity, would PJ administration be equally effective if coadministered with an ACE inhibitor or should we avoid such a co-administration?

Fourth, do authors consider that the use of PJ indeed improved CV health of hypertensives that they use it and if yes why?

It would be interesting and useful if these issues were sorted out.

\section{CONFLICT OF INTEREST}

The authors confirm that this article content has no conflicts of interest.

\section{ACKNOWLEDGEMENTS}

Declared none.

\section{REFERENCES}

[1] Tziomalos K, Doumas M, Athyros VG. No-pharmacological Intervention: Pomegranate juice for the treatment of arterial hypertension and the improvement of cardiovascular health status. Open Hypertens J 2013 [in press]

[2] Eussen SR, Verhagen H, Klungel OH, et al. Functional foods and dietary supplements: products at the interface between pharma and nutrition. Eur J Pharmacol 2011; 668 Suppl 1:S2-9.

[3] Lynn A, Hamadeh H, Leung WC, Russell JM, Barker ME. Effects of pomegranate juice supplementation on pulse wave velocity and blood pressure in healthy young and middle-aged men and women. Plant Foods Hum Nutr 2012; 67: 309-14.

Received: September 01,2013 Accepted: September 01, 2013

(C) Evdoxia K. Mitsiou; Licensee Bentham Open.

This is an open access article licensed under the terms of the Creative Commons Attribution Non-Commercial License (http:/creativecommons.org/ licenses/by-nc/3.0/) which permits unrestricted, non-commercial use, distribution and reproduction in any medium, provided the work is properly cited. 